\title{
ROLE OF ACTIVATED CHARCOAL IN LIMITING THE PROGRESSION OF CHRONIC KIDNEY DISEASE IN ALBINO RATS
}

\author{
By \\ Bataa El-Kafoury, Nermine K. Saleh, Dalia A. Saad, M K Shawky, Nayra \\ Mehanna*, and Elsayed Ghonamy \\ Department of Medical Physiology, Faculty of Medicine, Ain Shams University, Egypt \\ *Department of Dairy and Food Microbiology, National Research Center, Egypt \\ Corresponding author: Dalia A. Saad \\ Email: drdalia2009@med.edu.asu.eg \\ Phone number: 01019585366
}

\begin{abstract}
Background: Chronic kidney disease (CKD) is characterized by impaired kidney function, progressive kidney damage, unbalanced gut microbiota and disrupted intestinal mucosal barrier function. The damaged intestinal barrier functions mediated mostly by urea, allows influx of toxic products such as indoxyl sulphate that cause systemic inflammation. Activated charcoal is a universal antidote for the majority of poisons. Activated charcoal was suggested as a supplementary treatment for patients with CKD to remove waste products such as urea, indoxyl sulphate and other toxins .
\end{abstract}

Objectives: This study was designed to investigate the possible role of activated charcoal in limiting the influx of intestinal bacterial toxins to systemic circulation to limit progression of CKD in albino rats.

Material and Methods: Forty male white albino rats were divided into 4 equal groups. Sham operated control group (Group I): rats in this group were subjected to all steps of 5/6th nephrectomy except for kidney removal and sacrificed after 6 weeks, 5/6th nephrectomised group (Group II): were subjected to 5/6th nephrectomy operation, early charcoal treated 5/6th nephrectomised group (Group III ): were subjected to $5 / 6$ th nephrectomy operation and charcoal treatment $(4 \mathrm{~g} / \mathrm{kg} / \mathrm{day})$ started immediately after operation for 6 weeks, and late charcoal treated 5/6th nephrectomised group (Group IV): were subjected to 5/6th nephrectomy operation and charcoal treatment started 2 weeks after operation continued for 4 weeks .

Body weight and arterial blood pressure were measured before scarification after 6 weeks. Level of creatinine, urea, indoxyl sulphate and C- reactive protein were determined in the serum. Histological studies of pieces of terminal ileum and colon stained hematoxylin and eosin were done. Renal fibrosis index was assessed in remnant kidney stained with Masson Trichome .

Results: Group II had elevated serum level of urea, creatinine, indoxyl sulfate and C- reactive protein, colonic erosions and renal fibrosis compared to control group. Group III showed decreased level of serum creatinine, urea, indoxyl sulphate and C-reactive protein with partial restoration of the colonic mucosal integrity and reduction in renal fibrosis. Group IV had altered serum creatinine, urea and C- reactive protein but not serum indoxyl sulphate. Arterial blood pressure elevated in all studied groups compared to control group and was not affected by charcoal administration.

Conclusion: Activated charcoal has the ability to limit progression of CKD and the fibrotic changes in the kidney as well as to limit the associated intestinal barrier disruption, and the early therapy was more significant compared to late interference .

Key Words: Chronic kidney disease, indoxyl sulfate, activated charcoal, intestinal barrier. 


\section{INTRODUCTION}

Chronic kidney diseases (CKD) remain a major public health burden, and its prevalence is constantly growing.

In CKD, the colon becomes the major excretory organ to maintain body homeostasis. This adaptive response leads to severe consequences for the gut environment. Serum urea accumulation during CKD increases urea in? ux into the intestinal lumen, where urease producing bacteria hydrolyze it into ammonia and ammonium hydroxide, consequently increasing intestinal $\mathrm{pH}$ and promoting mucosal irritation and structural alterations to the gut barrier (Macfarlane and Macfarlane, 2011). The damaged "leaky gut" allows translocation of bacteria and toxins into the systemic circulation, promoting chronic inflammation which drives adverse cardiovascular outcomes and CKD progression (Lau et al., 2015).

High serum levels of indoxyl sulfate and p-cresol sulfate negatively correlate with kidney functions and have been considered essential factors in the development of systemic in?ammation. Also, indoxyl sulphate accumulation was found to cause interstitial fibrosis in renal tubular cells (Liu et al., 2018). The in? ux of these uremic toxins from the intestine increases and may affect the renal functions. Trials to limit influx of these toxins from the intestine which may help to decrease progression in CKD (Vanholder and Glorieux, 2015).

Activated charcoal has been shown to remove waste products such as urea, indoxyl sulphate and other urinary toxins, and augment the dialysis process (Schulman, 2012).
Administration of activated charcoal in animal models of chronic renal disease has been shown to reduce oxidative stress and inflammation and retard progression of renal disease (Bolati et al., 2012). The effects of activated charcoal have been primarily attributed to its ability to limit formation and absorption of indoxyl sulfate and p-cresol sulfate (Ito et al., 2013).

This study was designed to investigate the possible role of activated charcoal in limiting the influx of intestinal bacterial toxins to systemic circulation to limit progression of CKD in experimental albino rats.

\section{MATERIALS AND METHODS}

The present study was performed on 40 adult male albinos Wister rats initially weighing $150-250 \mathrm{~g}$. The rats were purchased from Research Institute of Ophthalmology (Giza). They were maintained in the (MASRI) Animal House in animal cages $(50 \times 30 \times 20 \mathrm{~cm})$ each cage contained 5 rats under controlled conditions of temperature $\left(25 \pm 2{ }^{\circ} \mathrm{C}\right)$ and relative humidity of $50-70 \%$. Rats were allowed standard pelleted chow and tap water ad libitum with normal light/ dark cycle. They were acclimatized to the laboratory conditions for a week prior to experimental procedures to decrease the possible discomfort of animals.

Animals were not exposed to unnecessary pain or stress and animal manipulation was performed with maximal care and hygiene. Surgical procedure ran under anesthesia to avoid induction of pain in animals. At the end of experiment, animals were killed by overdose of anesthesia. Animal remains disposal occurred by incineration. 


\section{ROLE OF ACTIVATED CHARCOAL IN LIMITING THE PROGRESSION... 45}

\section{Experimental design:}

Rats were divided into 4 equal groups. Sham operated control group (Group I) were subjected to all steps of 5/6th nephrectomy except for kidney removal, 5/6th nephrectomised group (Group II) were subjected to 5/6th nephrectomy operation (Sugano et al., 2008), early charcoal treated 5/6th nephrectomised group (Group III) were subjected to 5/6th nephrectomy operation and charcoal treatment started immediately after operation for 6 weeks, and late charcoal treated 5/6th nephrectomised group (Group IV): were subjected to 5/6th nephrectomy operation and charcoal treatment started 2 weeks after operation continued for 4 weeks. Rats were sacrificed after 6 weeks of starting the experiment.

Charcoal treatment: activated charcoal powder (Vaziri et al., 2013) with little modification) was dissolved in $15 \mathrm{ml}$ warm distilled water, and then given in the morning by gavage to the rats in a dose of $4 \mathrm{~g} / \mathrm{kg} / \mathrm{day}$. The charcoal solution was freshly prepared daily .

5/6 ${ }^{\text {th }}$ nephrectomy: After isoflurane anesthesia, the rat was put in prone position, a small incision was made on the back of the rat to expose the kidney and the right kidney and two third of the left kidney was removed with one week apart under ether anesthesia. The incisions were closed using 2-0 chromic catgut for the muscle and silk thread for the skin Sugano et al. (2008). Asepsis using Baneocin antibiotic powder (Bacitracin + Neomycin, Pharco pharmaceuticals Co., Egypt) was insured during the operation and daily after that till wound healing.

Experimental Procedures: Body weight and arterial blood pressure were determined for all groups initially and one day before sacrification. Arterial blood pressure (SBP, DBP and MPB) was measured using the non-invasive small animal tail blood pressure system (NIBP200A, Biopac systems Inc; USA).

On the day of sacrification, overnight fasted rats were anesthetized with i.p. injection of thiopental sodium (EIPICO, Egypt), in a dose of $40 \mathrm{mg} / \mathrm{kg} \mathrm{B.W}$.

Blood samples were collected for determination of serum level of creatinine (Bartles et al., 1972) and urea (Fawcett and Soctt, 1960) by a calorimetric method using kits supplied by Bio-Diagnostic, Egypt. Indoxyl sulphate was determined by Eliza technique using kits supplied by Shanghahi YL Biotecin Co.,Ltd., serum CRP (Quantitative Level), according to Mitra and Panja (2005), using kits supplied by BioVendorLaboratornmedic haa.s, Karasek, Brno, Czech Republic.

Histological studies: Samples of terminal ileum and colon were fixed in $10 \%$ formalin, embedded in paraffin, cut into 4$\mu \mathrm{m}$ sections and stained with hematoxylin and eosin. Samples of remnant kidneys were fixed $10 \%$ formalin, embedded in paraffin, cut into $5-\mu \mathrm{m}$ sections and stained with hematoxylin and eosin. In addition, glomerular sclerosis and renal ?brosis were assessed by Massontrichrome staining. The proportion of the ?brotic area was measured using ImagePro Plus 3.0 (Media Cybernetics, Silver Spring, MD, USA) (Kelly et al., 2004). Images were digitized and captured with a CCD camera connected to a personal computer .

\section{Statistical analysis:}

All results in the present study were expressed as mean \pm SEM of the mean. Statistical Package for the Social Sciences (SPSS, Inc., Chicago, IL, USA) program, version 20.0 was used to compare significance between each two groups. One -Way ANOVA (Analysis of 
Variance) for difference between means of different groups was performed on results obtained in the study. Differences were considered significant by LSD when $\mathrm{p} \leq 0.05$.

\section{RESULTS}

Results of serum creatinine, urea, indoxyl sulphate and $\mathrm{C}$-reactive protein (Table 1):

Levels of both creatinine and urea were significantly increased in all studied groups compared to sham group. Both parameters significantly decreased in early and late charcoal -treated groups in comparison to $5 / 6^{\text {th }}$ nephrectomy group. Late charcoal -treated group showed nonsignificant change in level of both creatinine and urea compared to early charcoal-treated group.

In comparison to control rats, indoxyl sulphate level significantly elevated in $5 / 6^{\text {th }}$ nephrectomy and late charcoaltreated rats in comparison to control rats, while it was non-significantly changed in early charcoal treated rats. Indoxyl sulfate level showed significant decrease in early charcoal treated rats compared to both $5 / 6^{\text {th }}$ nephrectomy rats and late charcoal treated rats

C -reactive protein significantly raised in all studied groups in comparison to control rats. Upon early and late treatment, C-reactive protein significantly decreased in comparison to $5 / 6^{\text {th }}$ nephrectomy group. Late charcoal-treated group showed non-significant change in $\mathrm{C}$ -reactive protein level compared to early charcoal treated one.

Table (1): Serum level of creatinine, urea, indoxyl sulphate and C-reactive protein in all studied groups (Mean \pm SEM)

\begin{tabular}{|c|c|c|c|c|}
\hline Parameters & Group I & Group II & Group III & Group IV \\
\hline Creatinine (mg/dl) & $0.6 \pm 0.04$ & $\begin{array}{c}2.1 \pm 0.1 \\
\mathbf{a}\end{array}$ & $1.5 \pm 0.08 \mathbf{a}, \mathbf{b}$ & $\begin{array}{c}1.6 \pm 0.06 \mathbf{a}, \\
\mathbf{b}\end{array}$ \\
\hline Urea (mg/dl) & $30 \pm 2.4$ & $118.8 \pm 10.8 \mathbf{a}$ & $\begin{array}{c}84 \pm 4.6 \\
\mathbf{a}, \mathbf{b}\end{array}$ & $\begin{array}{c}91 \pm 5.7 \\
\mathbf{a}, \mathbf{b}\end{array}$ \\
\hline Indoxyl sulphate $\mathbf{( \mu g / m l )}$ & $2.7 \pm 0.4$ & $\begin{array}{c}6.1 \pm 0.7 \\
\mathbf{a}\end{array}$ & $\begin{array}{c}3.4 \pm 0.7 \\
\mathbf{b}\end{array}$ & $\begin{array}{c}5 \pm 0.3 \\
\mathbf{a}, \mathbf{c}\end{array}$ \\
\hline C- Reactive Protein $(\mathbf{n g} / \mathbf{l})$ & $72 \pm 10.5$ & $201 \pm 15.7 \mathbf{a}$ & $\begin{array}{c}130 \pm 13.8 \\
\mathbf{a}, \mathbf{b}\end{array}$ & $\begin{array}{c}131 \pm 7.9 \\
\mathbf{a}, \mathbf{b}\end{array}$ \\
\hline
\end{tabular}

a: statistically significant from Group I

b: statistically significant from Group II

c: statistically significant from Group III

Arterial blood pressure and body weight changes(Table 2):

SBP, DBP and MBP significantly increased in all studied rats compared to control rats. Treated rats showed nonsignificant changes in SBP, DBP and MBP in comparison to 5/6th nephrectomy rats. 
ROLE OF ACTIVATED CHARCOAL IN LIMITING THE PROGRESSION... 47

Table (2): Changes in systolic (SBP), diastolic(DBP) and mean arterial blood (MBP) pressure in all studied groups (Mean \pm SEM)

\begin{tabular}{|c|c|c|c|c|}
\hline Groups & Group I & Group II & Group III & Group IV \\
\hline $\mathrm{SBP}(\mathrm{mmHg})$ & $120 \pm 2.3$ & $\begin{array}{c}128 \pm 1.7 \\
\mathbf{a}\end{array}$ & $\begin{array}{c}128 \pm 2.8 \\
\mathbf{a}\end{array}$ & $\begin{array}{c}133 \pm 1.5 \\
\text { a }\end{array}$ \\
\hline DBP (mmHg) & $86 \pm 2$ & $\begin{array}{c}95 \pm 1.9 \\
\mathbf{a}\end{array}$ & $\begin{array}{c}97 \pm 0.8 \\
\mathbf{a}\end{array}$ & $\begin{array}{c}100 \pm 1.8 \\
\mathbf{a}\end{array}$ \\
\hline MBP(mmHg) & $97 \pm 1.5$ & $\begin{array}{c}107 \pm 1.5 \\
\text { a }\end{array}$ & $\begin{array}{c}108 \pm 1.6 \\
\text { a }\end{array}$ & $\begin{array}{c}112 \pm 1.8 \\
\mathbf{a}\end{array}$ \\
\hline
\end{tabular}

a: statistically significant from Group I

In comparison to control rats, body weight significantly decreased in $5 / 6^{\text {th }}$ nephrectomy rats early charcoal-treated group, while body weight nonsignificantly different in late charcoaltreated group. Early charcoal-treated group showed non-significant difference

in body weight changes in comparison to 5/6th nephrectomy group. Late charcoaltreated group showed significant increase in body weight in comparison to both 5/6th nephrectomy and early charcoaltreated group (Table 3).

Table (3): Changes in body weight (BW change) and renal fibrosis index in all studied groups (Mean \pm SEM)

\begin{tabular}{|c|c|c|c|c|}
\hline Groups & Group I & Group II & Group III & Group IV \\
\hline BW change (gm) & $31.2 \pm 2.1$ & $\begin{array}{c}17.6 \pm 1.9 \\
\mathbf{a}\end{array}$ & $\begin{array}{c}23.2 \pm 1.6 \\
\mathbf{a}\end{array}$ & $\begin{array}{c}32.7 \pm 2.4 \\
\mathbf{b}, \mathbf{c}\end{array}$ \\
\hline $\begin{array}{c}\text { Renal fibrosis index } \\
(\%)\end{array}$ & $2.78 \pm 0.4$ & $\begin{array}{c}24.5 \pm 2 \\
\mathbf{a}\end{array}$ & $\begin{array}{c}6.69 \pm 1 \\
\mathbf{b}\end{array}$ & $\begin{array}{c}12 \pm 2.2 \\
\mathbf{a}, \mathbf{b}\end{array}$ \\
\hline
\end{tabular}

a: statistically significant from Group I

b: statistically significant from Group II

c: statistically significant from Group II

\section{Histological changes:}

\section{Changes in percentage of renal fibrosis}

(Table 3, Fig. 1):

In comparison to control rats, renal fibrosis significantly increased in 5/6th nephrectomy rats and in late charcoaltreated rats, while it showed nonsignificant change in early charcoal- treated rats. Both early and late charcoaltreated rats had significant decrease in renal fibrosis in comparison to $5 / 6^{\text {th }}$ nephrectomy rats.

Late charcoal-treated rats showed nonsignificant change in renal fibrosis compared to early charcoal treated rats. 

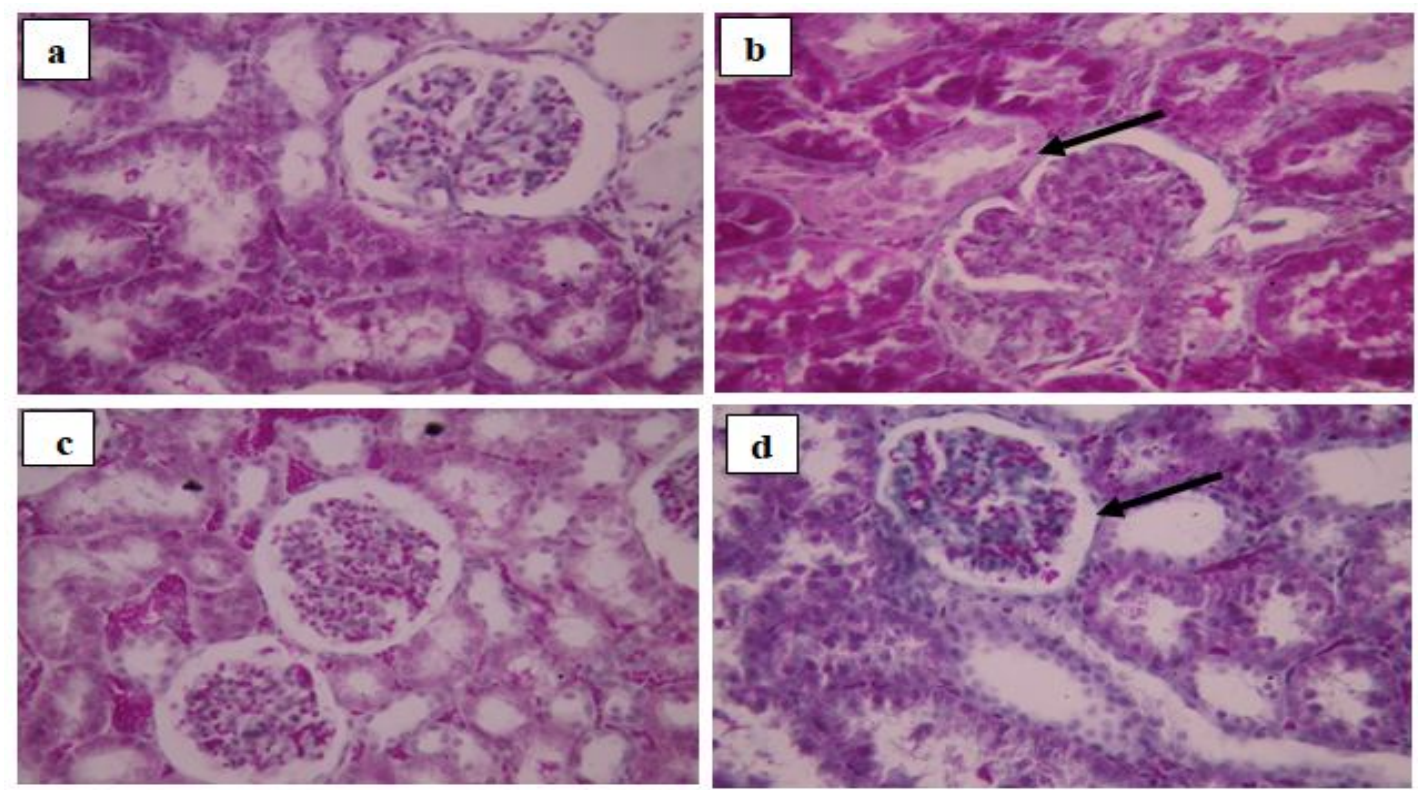

Figure (1): Histological changes in kidney remnants in all studies groups (Masson trichrome stained $400 \mathrm{X}$ ): a: Control group, b: 5/6 nephrectomy group, c: Early charcoal-treated $5 / 6^{\text {th }}$ nephrectomy group and d: Late charcoaltreated $5 / 6^{\text {th }}$ nephrectomy group.

Histological changes in the intestine (Fig. 2):

Control rats had normal crypts, villi and intact goblet cells. Intestinal sections of $5 / 6^{\text {th }}$ nephrectomy rats and late charcoal-treated rats showed atrophied crypts and villi with shedding of mucosa while early charcoal-treated rats had nearly normal crypt and villi.

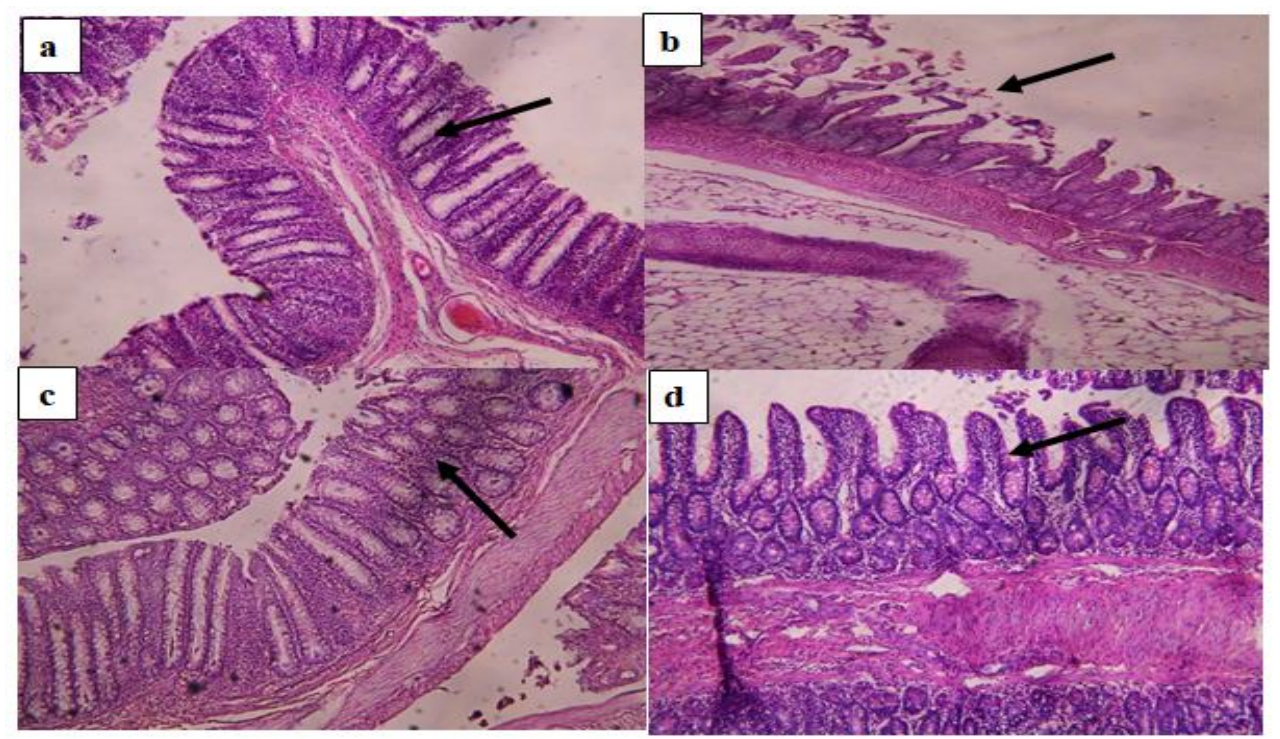

Figure (2): Histological changes in intestine in all studies groups (H\&E X400) a:Control group, b: 5/6 nephrectomy group, c: Early charcoal-treated 
ROLE OF ACTIVATED CHARCOAL IN LIMITING THE PROGRESSION... 49

\section{$5 / 6^{\text {th }}$ nephrectomy group and d: Late charcoal-treated $5 / 6^{\text {th }}$ nephrectomy group \\ DISCUSSION}

In the present work, the $5 / 6^{\text {th }}$ nephrectomy rats showed a significant increase in the concentrations of serum creatinine, urea, and indoxyl sulphate toxins as compared to the control group. These increases were demonstrative of the failure of kidney functions which confirm the success of our model of $5 / 6^{\text {th }}$ nephrectomy as a CKD model (Sugano et al., 2008). In addition, the histological findings in the kidney tissues added more confirmation in the form of glomerular injury, tubular cast and interstitial fibrosis as well as increased fibrotic index.

Indoxyl sulphate, the protein-bound uremic solute, is known to be produced in the large intestine by the bacteria from tryptophan, absorbed from the colon, metabolized in liver into sulphurconjugated substances, and excreted in the urine from the kidney (Takada et al., 2018). Once accumulated by renal impairment, these substances cause renal tissue damage through oxidative stress (Yoshifuji et al., 2018). Thus, the high level of indoxyl sulphate in $5 / 6^{\text {th }}$ nephrectomy rats could be considered as a result, as well as a cause for further renal impairment. The decreased clearance of indoxyl sulphate in renal impairment was previously attributed to inhibition of its primary apical transporter in the kidney (Mutsaers et al., 2011).

In addition, the $5 / 6^{\text {th }}$ nephrectomy group in this study showed a significant increase in plasma $\mathrm{C}$-reactive protein in comparison to the control group which points to presence of systemic inflammation.
The occurrence of a state of chronic systemic inflammation in CKD is suggested to be due to several factors including increased production of proinflammatory cytokines and/or decreased their clearance, oxidative stress, and acidosis in addition to intestinal dysbiosis (Akchurin and Kaskel, 2015).

The intestinal dysbiosis is believed to be caused by the influx of urea and other retained toxins in $\mathrm{CKD}$, impairing the intestinal barrier function and thus promoting inflammation throughout the gastrointestinal tract. Moreover the damaged "leaky gut" in CKD allows translocation of bacteria and toxins including indoxyl sulphate- into the systemic circulation leading to more renal impairment in a positive feed- back like cycle (Lau et al., 2018).

Referring to our histological findings in this study, in $5 / 6^{\text {th }}$ nephrectomy group compared to control group, the intestinal villi were atrophied with absent crypts and inflammatory cells invasion, in addition to the significantly high renal fibrosis. These findings could be attributed to high level of indoxyl sulphate in $5 / 6^{\text {th }}$ nephrectomy group. Moreover in this study positive correlation between indoxyl sulphate and both urea and creatinine was noted.

This concept could be supported by the previously mentioned effects of indoxyl sulphate on podocytes where it caused formation of cytoplasmic vacuoles due to down-regulation of structural actins, integrins, and collagen (Ichii et al., 2014). Also, indoxyl sulphate accumulation was found also to cause interstitial fibrosis in renal tubular cells (Liu et al., 2018). 
In comparison with control group, there was significant reduction in weight gain in $5 / 6^{\text {th }}$ nephrectomy rats. This was known to be due to the imbalance between anabolism and catabolism.

CKD patients had increased protein catabolism in muscle caused by metabolic acidosis, defective insulin signalling, abnormal appetite regulation, impaired microRNA responses and impaired ability of IGF-1 to regulate muscle protein synthesis (Xiaonan and William, 2014). Earlier, Hung et al. (2011) reported that increased levels of circulating proinflammatory cytokines, including IL6 , TNF- $\alpha$ and C-reactive protein in CKD cause muscle wasting .

There was significant increase in systolic, diastolic and mean arterial blood pressure in $5 / 6^{\text {th }}$ nephrectomy rats compared to control rats. This could be explained by the uraemia and increased level of indoxyl sulphate .

Hypertension and vascular dysfunction induced by uremia is mediated by atherosclerosis, arterial stiffness, vascular calcification, intimal thickening and vascular smooth muscle proliferation (Mitsnefes, 2012). Indoxyl sulfate was reported to stimulate proliferation of human aortic smooth muscle cells (Barreto et al., 2009), to increase free radicle release (Muteliefu et al., 2009) and to inhibit NO production in human vascular endothelial cells (Tumur and Niwa, 2009).

Activated charcoal is a high purity porous carbon adsorbent utilized to adsorb and remove uremic toxins from the gut by excreting the toxins with the faeces (Cha et al., 2016).
The present study demonstrated renoprotective effects of activated charcoal treated $5 / 6^{\text {th }}$ nephrectomy groups. The charcoal treated groups showed a significant reduction in serum urea and creatinine as compared to the $5 / 6^{\text {th }}$ nephrectomy group.

These results came in accordance with Yoshifuji et al. (2018) but in contrast to Schulman et al. (2015) who failed to demonstrate the delay of the progression of chronic kidney disease by administration of activated charcoal. The reno-protective effects in our study might be due to administration of activated charcoal in the earlier stages of chronic kidney disease in this study and /or uncompliance to charcoal by the patients in the other study. The significant reduction in serum creatinine and urea concentrations in charcoal treated groups could be suggestive for the delay in the progression of chronic kidney disease .

The results in this study showed a significant decrease in the levels of indoxyl sulphate in the charcoal treated groups as compared to the untreated CKD group especially in the early charcoal treated group. In addition, a positive significant correlation between the serum levels of indoxyl sulphate and those of urea and creatinine was found.

Same results were obtained by $\mathrm{Cao}$ et al. (2015) who showed that serum indoxyl sulphate levels has an inverse relationship with kidney functions.

This decreased indoxyl sulphate could be primarily attributed to the charcoal's ability to limit formation and absorption of indoxyl sulphate hence alleviating the overload of indoxyl sulphate on proximal tubular epithelial cells and podocytes 


\section{ROLE OF ACTIVATED CHARCOAL IN LIMITING THE PROGRESSION... 51}

(Shimizu et al., 2011 and Ito et al., 2013). Also, the ability of activated charcoal to decrease the levels of indoxyl sulphate is suggested to be through its ability to ameliorate the intestinal barrier disruption thus blocking the entry of this toxic molecule (Vaziri et al., 2013). Recently, another plausible mechanism for the restoration of intestinal barrier structure by activated charcoal is restoration of Lactobacillus, a butyrate-producing microbe. Lactobacillus is considered to be one of the key regulators to maintain and form the tight junction protein in the gut (Yoshifuji et al., 2018).

These findings could be correlated to our histological results that showed decreased fibrotic index, better histological findings in kidney tissue and nearly normal non disrupted appearance of intestinal villi in charcoal treated groups.

The anti-inflammatory effect of activated charcoal manifested in significant decrease in C-reactive protein compared to untreated group could be explained by its ability to decrease serum indoxyl sulphate as well as its ability to restore the intestinal barrier function which results in the blockade of toxin entry from the intestine (Yoshifuji et al., 2018).

Activated charcoal treated group showed an increase in weight gain in comparison to untreated group although the increase in weight gain was significant in late charcoal group and insignificant in early charcoal treated group. The improvement in weight gain could be explained by the decrease of serum inflammatory mediators in charcoal treated groups (Hung et al., 2011).
The early and late charcoal treatment failed to decrease systolic and diastolic blood pressure significantly in comparison to $5 / 6^{\text {th }}$ untreated group in spite of decrease in serum urea, creatinine and indoxyl sulphate. This may be attributed to other factors implemented in hypertension in renal impairment such as increased sympathetic activity or disrupted renin angiotensin system (Hamrahian and Falkner, 2017).

Thus, this study confirmed the ability of activated charcoal to limit progression of CKD and the fibrotic changes in the kidney as well as to limit the associated intestinal barrier disruption. Also this study added that early therapy is more significant compared to late interference.

\section{ACKNOWLEDGEMENT}

We would like to express our sincere appreciation to Professor Amany Elshawarby, Professor of Histology and Head of Histology Department, Faculty of Medicine, Ain-Shams University, for her great effort in assessing our histology specimen and reporting histological studies.

\section{REFERENCES}

1. Akchurin OM and Kaskel F (2015): Update on inflammation in chronic kidney disease. Blood Purification, 39(1-3): 84-92.

2. Barreto FC, Barreto DV, Liabeuf S, Meert N, Glorieux G, Temmar M, Choukroun G, Vanholder R and Massy ZA (2009): Serum indoxyl sulfate is associated with vascular disease and mortality in chronic kidney disease patients. Clin J Am Soc Nephrol, 4: 15511558.

3. Bartles H, Bohmer $M$ and Heirli C (1972): Serum creatinine determination without protein precipitation. Clin Chem Acta, 37: 193- 197. 
4. Bolati D, Shimizu $H$ and Niwa $T$ (2012): AST-120 ameliorates epithelial-tomesenchymal transition and interstitial fibrosis in the kidneys of chronic kidney disease rats. J Ren Nutr, 22(1):176-180.

5. Cao XS, Chen J, Zou JZ, Zhong YH, Teng J, Ji J, Chen ZW, Liu ZH, Shen B, Nie YX, Lv WL, Xiang FF, Tan X and Ding XQ (2015): Association of indoxyl sulfate with heart failure among patients on hemodialysis. Clin J Am Soc Nephrol, 10: 111-119.

6. Cha RH, Kang SW, Park CW, Cha DR, Na KY, Kim SG, Yoon SA, Han SY, Chang JH, Park SK, Lim CS and Kim YS (2016): A randomized, controlled trial of oral intestinal sorbent AST-120 on renal function deterioration in patients with advanced renal dysfunction. Clin J Am Soc Nephrol, 11: 559567.

7. Fawcett JK and Soctt JE (1960): A rapid and precise method for the determination of urea. $\mathrm{J}$ Clin Path, 13: 156- 159.

8. Hamrahian SM and Falkner B. (2017): Hypertension in Chronic Kidney Disease. Adv Exp Med Biol., 956: 307-325.

9. Hung AM, Ellis CD, Shintani A, Booker C and Ikizler TA (2011): IL-1 $\beta$ receptor antagonist reduces inflammation in hemodialysis patients. J Am Soc Nephrol, 22:437-442.

10. Ichii O, Otsuka-Kanazawa S, Nakamura T, Ueno M, Kon Y, Chen W, Rosenberg AZ and Kopp JB (2014): Podocyte injury caused by indoxyl sulfate, a uremic toxin and arylhydrocarbon receptor ligand. PLoS ONE, 9: e108448.

11. Ito S, Higuchi Y, Yagi Y, Nishijima F, Yamato H, Ishii H, Osaka $M$ and Yoshida $M$ (2013): Reduction of Indoxyl Sulfate by AST120 Attenuates Monocyte Inflammation Related to Chronic Kidney Disease. J Leukoc Biol, 93(6):837-845.

12. Kelly DJ, Zhang Y and GowR and Gilbert RE (2004): Tranilast attenuates structural and functional aspects of renal injury in the remnant kidney model. J Am Soc Nephrol, 15: 2619-2629.
13. Lau WL, Kalantar-Zadeh $K$ and Vaziri ND (2015): The gut as a source of inflammation in chronic kidney disease. Nephron, 130(2):9298.

14. Lau WL, Savoj J, Nakata MB and Vaziri ND (2018): Altered microbiome in chronic kidney disease: Systemic effects of gut-derived uremic toxins. Clin Sci, 132:509-522.

15. Liu WC , Tomino Y and Lu KC (2018): Impacts of Indoxyl Sulphate and p-Cresol Sulfate on Chronic Kidney Disease and Mitigating Effects of AST-120, Toxins , 10 (9), 367.

16. Macfarlane GT and Macfarlane S (2011): Fermentation in the human large intestine: its physiologic consequences and the potential contribution of prebiotics. J Clin Gastroenterol, 45:S120 -S127.

17. Mitra B and Panja M (2005): High sensitive C-reactive protein: a novel biochemical markers and its role in coronary artery disease. J Assoc Physicians India, 53: 25-32.

18. Mitsnefes MM. (2012): Cardiovascular disease in children with chronic kidney disease. J Am Soc Nephrol., 23 (4) :578 - 585.

19. Muteliefu G, Enomoto A and Niwa T (2009): Indoxyl sulfate promotes proliferation of human aortic smooth muscle cells by inducing oxidative stress. J Ren Nutr., 19:29-32.

20. Mutsaers, HA, van den Heuvel LP, Ringens LH, Dankers AC, Russel FG, Wetzels JF, Hoenderop JG and Masereeuw R (2011): Uremic toxins inhibit transport by breast cancer resistance protein and multidrug resistance protein 4 at clinically relevant concentrations. PLoS One 6, e18438.

21.Schulman G (2012): A nexus of progression of chronic kidney disease: tryptophan, pro? brotic cytokines, and charcoal. J Ren Nutr, 22(1):107-113.

22. Schulman G, Berl T, Beck GJ, Remuzzi G, Ritz E, Arita K, Kato A and Shimizu M (2015): Randomized Placebo-Controlled EPPIC Trials of AST-120 in CKD. J Am Soc Nephrol, 26: 1732-1746.

23. Shimizu H, Bolati D, Adijiang A, Muteliefu G, Enomoto A, Nishijima F, Dateki $M$ and 


\section{ROLE OF ACTIVATED CHARCOAL IN LIMITING THE PROGRESSION... 53}

Niwa T (2011): NF-B plays an important role in indoxyl sulfate-induced cellular senescence, fibrotic gene expression, and inhibition of proliferation in proximal tubular cells. Am J Physiol Cell Physiol, 301: C1201-C1212.

24. Sugano N, Wakino S, Kanda T, Tatematsu S, Homma K, Yoshioka K, Hasegawa K, Hara Y, Suetsugu Y, Yoshizawa T, Hara Y, Utsunomiya Y, Tokudome G, Hosoya T, Saruta $T$ and Hayashi K (2008): T-type calcium channel blockade as a therapeutic strategy against renal injury in rats with subtotal nephrectomy. Kidney Int., 73: 826834.

25. Takada T, Yamamoto T, Matsuo H, Tan JK, Ooyama K, Sakiyama M, Miyata H, Yamanashi Y, Toyoda Y, Higashino T, Nakayama A, Nakashima A, Shinomiya N, Ichida K, Ooyama H, Fujimori S and Suzuki H (2018): Identification of $A B C G 2$ as an Exporter of Uremic Toxin Indoxyl Sulfate in Mice and as a Crucial Factor Influencing CKD Progression. Sci Rep., 24;8(1), article number 11147.

26. Tumur $Z$ and Niwa T (2009): Indoxyl sulfate inhibits NO production and cell viability by inducing oxidative stress in vascular endothelial cells. Am J Nephrol, 29:551-557.

27. Vanholder R and Glorieux G (2015): The intestine and the kidneys:abad marriage can be hazardous. Clin Kidney J, 8:168-179.

28. Vaziri ND, Yuan J, Khazaeli M, Masuda Y, Ichii $H$ and Liu S. (2013): Oral activated charcoal adsorbent (AST-120) ameliorates CKD- induced intestinal epithelial barrier disruption. Am J Nephrol, 37(6): 518-525.

29. Xiaonan HW and William EM (2014): Mechanisms of muscle wasting in chronic kidney disease Nat Rev Nephrol, 10(9): 504516.

30. Yoshifuji A, Wakino S, Irie J, Matsui A, Hasegawa K, Tokuyama H, Hayashi K and Itoh H (2018): Oral adsorbent AST-120 ameliorates gut environment and protects against the progression of renal impairment in CKD rats Clinical and Experimental Nephrology, 22:1069-1078. 


\section{دور الفحم المنشط فى الحلد من تقلم مرض الكلي المزمن في الجرذان البيضاء}

باتعه الكافوري- رمين كمال- داليا عبد السلام- منى شوقي- نايره مهنا- السيد غنيمي

قسم الفسيولوجيا الطبيةـ. كلية الطبــ جامعة عين شمس

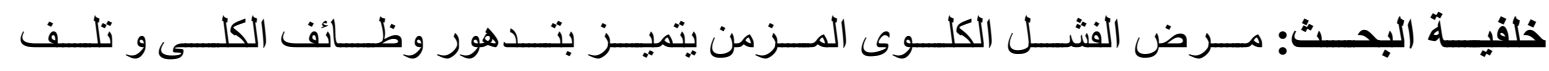

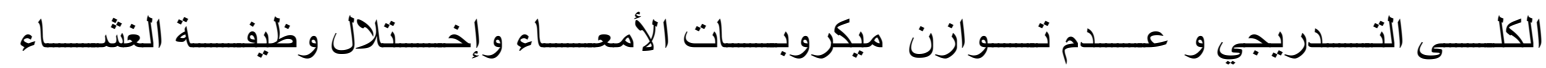

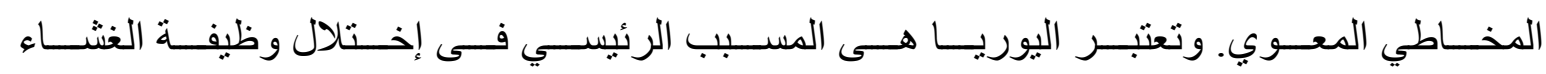

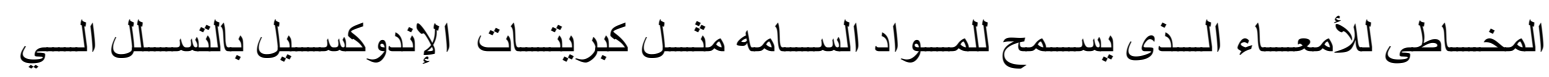

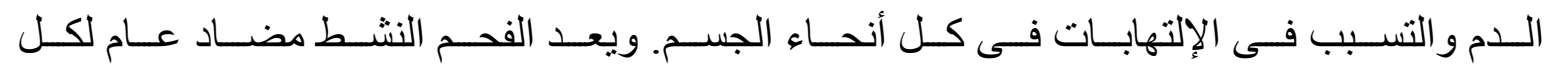

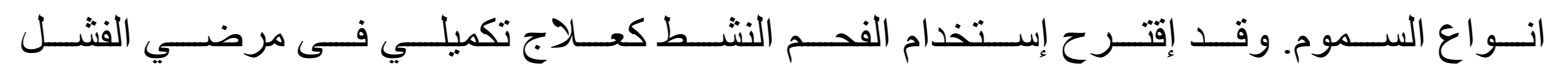

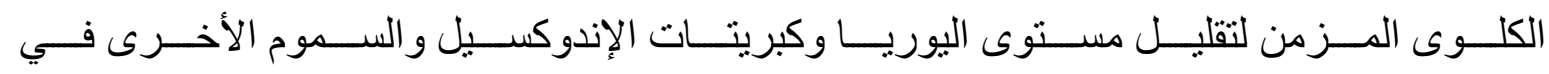

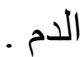

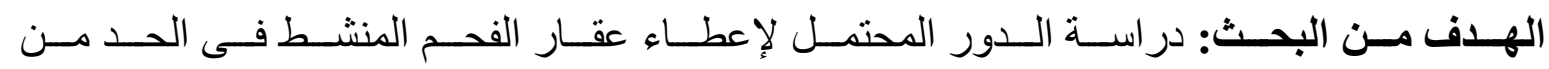

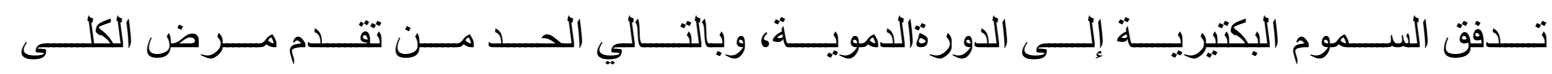

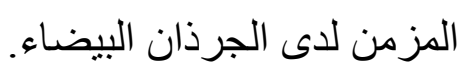

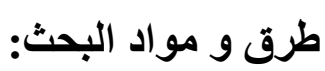

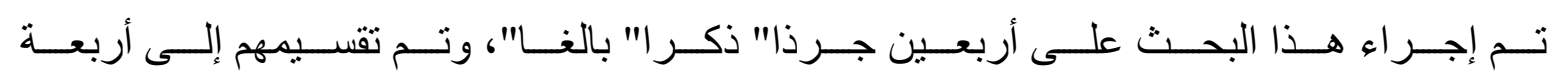

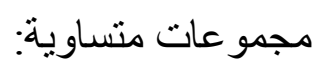
ه الدجمو عةالأولى: المجمو عة الضابطة.

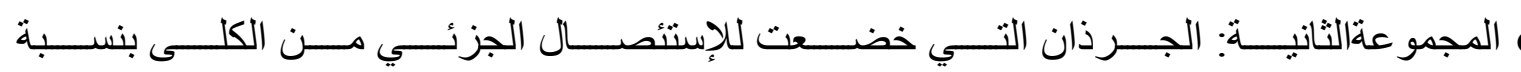
6/5 لمدة 6 أسابيع. 


\section{ROLE OF ACTIVATED CHARCOAL IN LIMITING THE PROGRESSION... 55}

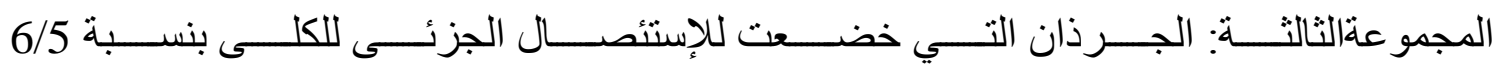

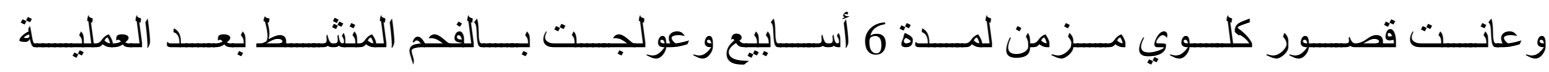
مباشرة.

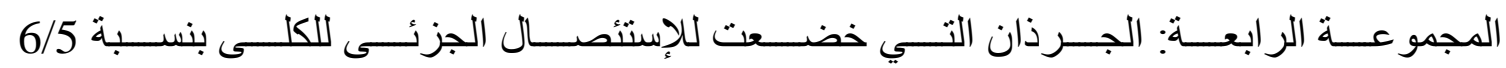

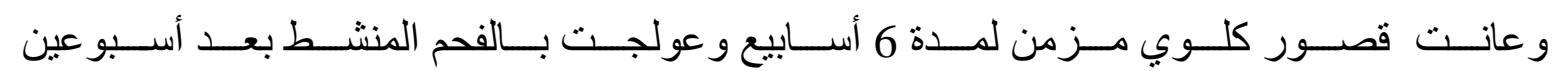
من إجر اء العملية .

وقد خضعت جميع الجرذان في نهاية الدر اسة للقياسات الآتية: 1- الوزن الأوَّلى للجسم و الوزن النهائى للجسم.

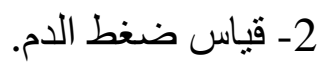
3- اختباروظائف الكلى (مستوى اليوريا فى الدم-الكرياتنين). 4- قياس نسبة كبريتات الإندوكسيل بالام. 5- البروتين التفاعلى سى. 6- الفحص الهستولوجى(فحص أنسجة الكلى). 7ـ الفحص الهستولوجى للأمعاء.

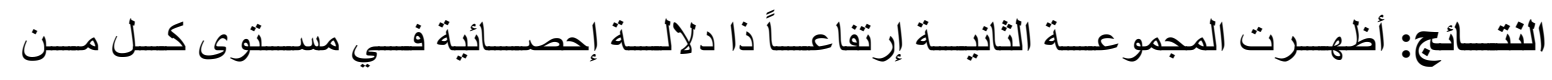

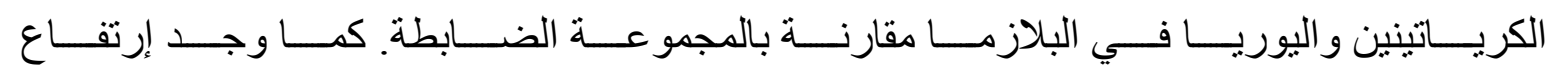

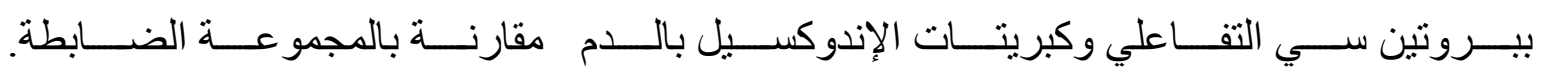

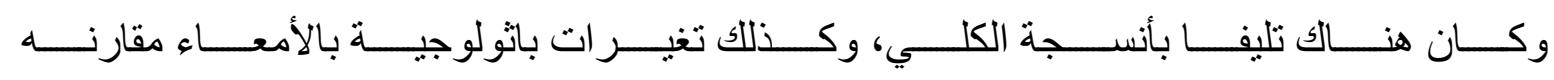
بالمجمو عة الضابطة.

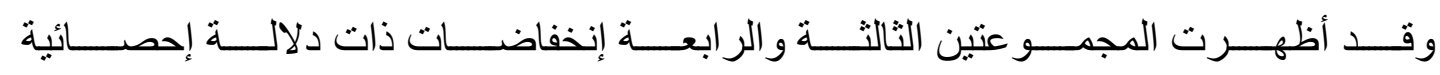

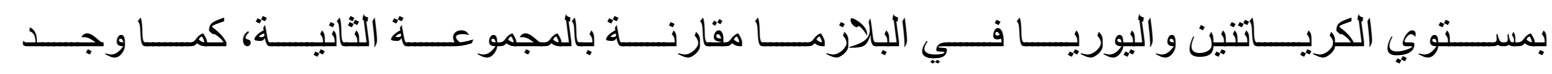

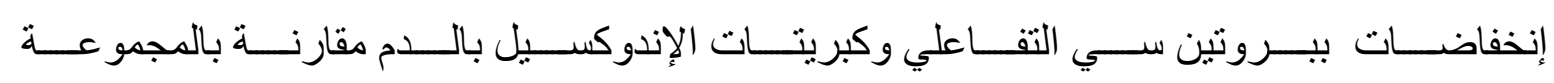

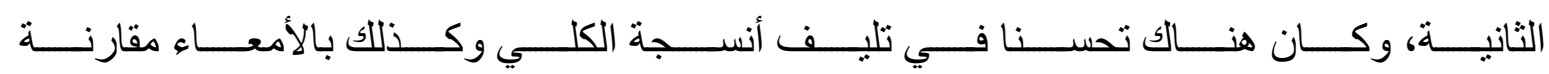
بالمجمو عة الثانية. 


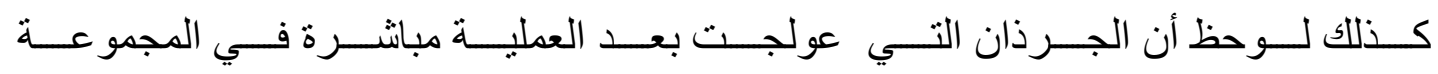

الثالثة قد تحسنت بصورة أكبر من التي بدأت العلاج بعد العملية بأسبو عين.

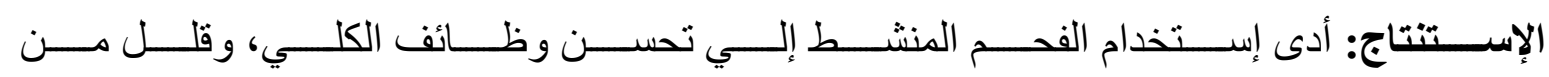

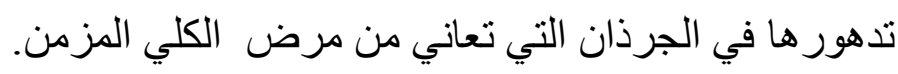

